\title{
PENGEMBANGAN SISTEM INFORMASI PENJUALAN DAN PEMBELIAN PADA TOKO PC TABLET
}

Nur Setyo Permatasari Putri W, R Rizal Isnanto, Ike Pertiwi Windasari

Program Studi Sistem Komputer Fakultas Teknik Universitas Diponegoro

Jl. Prof. H. Sudarto,S.H., Tembalang - Semarang

permatasari26setyo@gmail.com

Abstrak - Sistem informasi penjualan dan pembelian yang dimiliki oleh perusahaan masih mempunyai beberapa kekurangan yang menyebabkan terjadinya kesalahan data pada laporan yang dihasilkan. Dan juga meskipun perusahaan telah memiliki sistem informasi namun perusahaan masih sering melakukan proses transaksi dan pencatatan transaksi secara manual, sehingga kesalahan data tidak dapat terhindarkan lagi. Oleh karena itu, perusahaan membutuhkan sebuah sistem informasi penjualan dan pembelian yang memadai, untuk dapat menampilkan data lebih akurat dan lebih mudah dipahami dalam penggunaannya.

Pengembangan sistem informasi penjualan dan pembelian diawali dengan analisis kebutuhan sistem. Hal ini ditujukan untuk mendapatkan spesifikasi sistem yang sesuai. Kemudian dari data yang ada, dilakukan perancangan sistem informasi penjualan dan pembelian yang disesuaikan dengan kebutuhan perusahaan. Dalam tahapan perancangan, penggambaran proses bisnis sistem informasi dijelaskan dengan menggunakan DFD (Data Flow Diagram) dan untuk merepresentasikan data dalam sistem secara logis dilakukan dengan menggunakan ERD (Entity Relationship Diagram). Hasil dari perancangan kemudian diimplementasikan dengan menggunakan bahasa pemrograman PHP dan menggunakan sistem basis data MySQL. Perangkat yang digunakan adalah perangkat lunak Adobe Dreamweaver CS6 dan XAMPP.

Hasil pengujian sistem informasi penjualan dan pembelian menunjukkan bahwa semua fitur yang terdapat dalam sistem informasi dapat bekerja dengan baik seperti mengelola data transaksi, mengelola data admin, mengelola data barang dan mengelola data lainnya yang berhubungan dengan kegiatan pokok dalam transaksi ini. Pada sistem informasi penjualan dan pembelian juga disertakan fungsi untuk menampilkan laporan dari proses transaksi yang dilakukan oleh pengguna.

Kata kunci: sistem informasi penjualan dan pembelian, Data Flow Diagram, Entity Relationship Diagram, PHP, MySQL, $X A M P P$

\section{PENDAHULUAN}

Di era globalisasi yang berkembang pesat saat ini, internet merupakan teknologi yang memiliki cakupan sangat luas. Dimana internet terhubung secara online tanpa mengenal batas waktu dan tempat. Dalam hal ini, bila perusahaan menggunakan internet dalam sistem informasinya maka akn memberikan kemudahan bagi para pelangggan dalam mendapatkan informasi yang dibutuhkan dan juga perusahaan itu sendiri.

Salah satu aktivitas perusahaan yang terpenting adalah aktivitas penjualan dimana penjualan merupakan peran terpenting dana ujung tombak suatu perusahaan. Tujuan penjualan yang utama adalah mencapai tingkat volume penjualan yang besar yang tentunya menentukan kelangsungan hidup perusahaan dan mendatangkan laba bagi perusahaan serta pengembalian investasi yang telah ditanamkan. Karena hal tersebut disusunlah penelitian ini, dengan merancang sistem informasi penjualan yang menggunakan fasilitas internet sebagai media komunikasi sehingga diharapkan terjadinya proses penjualan yang lebih cepat, dimana pada penyusunan penelitian ini diharapkan memberi solusi penyelesain yang baik terhadap sistem informasi penjualan yang telah ada sebelumnya pada perusahaan yang bersangkutan.

Pada perusahaan ini, sistem informasi penjualan yang telah berjalan sebelumnya memiliki beberapa kesalahan (error) yang menyebabkan timbulnya ketidaknyamanan dalam penggunaan pada saat proses penjualan terjadi. Kesalahankesalahan yang dimiliki pada sistem informasi ini adalah seperti kurangnya kemudahan (user friendly) dalam penggunaan sistem dan terkadang kurang akuratnya data yang diberikan oleh sistem saat transaksi dilaksanakan.

Oleh karena itu, pengembangan sistem informasi penjualan ini bertujuan untuk memberikan tampilan antarmuka sistem yang lebih menarik sehingga mempermudah pengguna dalam melakukan kegiatan pada sistem. Sistem informasi penjualan yang dikembangkan ini juga bertujuan untuk memberikan pengguna kenyamanan dalam penggunaan sistem, serta diharapkan pada sistem ini telah memberikan solusi terhadap masalah-masalah yang dimiliki oleh sistem informasi penjualan sebelumnya ketika digunakan oleh pengguna.

\section{TINJAUAN PUSTAKA}

Terdapat beberapa tinjuauan pustaka yang diperoleh dari jurnal-jurnal penelitian tentang pengembangan sistem informasi dengan menggunakan metode prototyping. Ringkasan mengenai jurnal-jurnal tersebut akan dijelaskan dalam penjelasan berikut ini.

Jurnal pertama yang membahas mengenai pengembangan sistem informasi dengan metode prototyping memiliki judul "Pengembangan Sistem Informasi Apotek (Studi Kasus : Apotek Leuwi Sehat Majalengka". Pada jurnal ini membahas tentang pengembangan sistem informasi sebuah apotek yang pengembangannya menggunakan metode prototyping. Penggunaan metode prototyping ini bertujuan untuk mempermudah pengguna dan developer (pengembang) dalam merumuskan permasalahan yang dimiliki oleh sistem agar dapat dimengerti oleh kedua belah pihak secara langsung.

Jurnal kedua yang membahas mengenai pengembangan sistem informasi dengan metode prototyping memiliki judul "Rancang Bangun Sistem Informasi Simpan Pinjam Pada Koperasi Ganesa Indah Balai Konservasi Sumber Daya Alam 
(KSDA) Sum-Sel Dengan Menggunakan Metode Prototyping". Pada jurnal kedua ini membahas mengenai pengembangan sebuah sistem informasi yang berjalan pada koperasi simpan pinjam. Penulis jurnal menjelaskan bahwa tujuan dari penggunaan metode prototyiping pada pengembangan sistem informasi ini adalah untuk dapat mengembangkan sistem secara kilat namun akurat, sehingga pengguna dapat lebih memahami sistem tersebut.

Jurnal ketiga dan terakhir yang membahas mengenai pengembangan sistem informasi dengan metode prototyping memiliki judul "Rancang Bangun Sistem Penilaian Index Kepuasan Pegawai Terhadap Lingkungan Kerja Melalui Dashboard Terintegrasi Dengan Menggunakan Metode Prototype, Studi Kasus PT. PLN (PERSERO) Area Bali Selatan". Pada jurnal ini, penulis menjelaskan pemilihan penggunaan metode prototyping pada pengembangan sistem informasi yang dikembangkan metode ini dapat bertindak sebagai dasar untuk membuat sebuah spesifikasi sistem yang akan dikembangkan.

III.

\section{ANALISIS DAN PERANCANGAN SISTEM}

\section{A. Analisis Kebutuhan Sistem}

Analisis sistem memiliki tujuan untuk mempelajari prosedur yang sedang berjalan sekarang dan kebutuhan atau keinginan dari orang yang akan menggunakan aplikasi atau program yang akan dikembangkan ini. Tujuan dari perancangan sistem ini sceara garis besar adalah untuk menghasilkan bentuk perancangan yang dapat memenuhi kebutuhan akan penyelesaian masalah secara tepat dan benar.

Aplikasi Sistem Informasi Penjualan yang dibangun akan digunakan oleh dua orang pengguna yaitu admin dan kasir.

- Kebutuhan Fungsional

Kebutuhan fungsional merupakan pernyataan pelayanan sistem yang harus disediakan, bagaimana sistem bereaksi pada input tertentu dan bagaimana perilaku sistem pada situasi tertentu. Kebutuhan fungsional yang digunakan pada sistem informasi penjualan ini adalah :

- Fasilitas untuk mengelola data pengguna.

- Fasilitas untuk mengelola data barang.

- Fasilitas untuk mengelola data penjualan.

- Fasilitas untuk mengelola data pembelian.

- Fasilitas untuk mengelola data pemasok.

- Pengguna dibagi menjadi dua, yaitu Kasir dan Admin. Untuk Kasir, fasilitas yang disediakan adalah mengelola data penjualan dan mengelola data pembelian. Untuk Admin, fasilitas yang disediakan adalah mengelola data pengguna, mengelola data barang, mengelola data penjualan, mengelola data pembelian, dan mengelola data pemasok.

- Kebutuhan Non-Fungsional

Kebutuhan non-fungsional merupakan batasan layanan atau fungsi yang ditawarkan sistem seperti batasan waktu, batasan pengembangan proses, standarisasi, dan sebagainya. Kebutuhan non-fungsional yang digunakan pada sistem informasi penjualan ini adalah :

Operasional

- Keamanan
Penggunaan username dan password dalam form login untuk membedakan tipe user termasuk hak akses masing-masing.

- Interface / Antar muka

Antar muka pemakai atau user interface adalah bagian penguhubung antara program sistem informasi dengan pemakai. Kebutuhan terhadap antar muka yang diinginkan sebaik mungkin bersifat user friendly, artinya pengguna dapat menggunakan perangkat lunak yang dibuat dengan mudah dan senyaman mungkin untuk mendapatkan suatu informasi yang diinginkan oleh pengguna tersebut. Kebutuhan antar muka (interface) untuk suatu aplikasi yang dibuat didapatkan dari hasil observasi dari lingkungan dimana sistem akan dibangun.

\section{B. Pemodelan Perangkat Lunak}

Berikut adalah pemodelan perangkat lunak yang menggunakan Diagram konteks, Data Flow Diagram, dan Entity Relationship Diagram.

\section{Diagram Konteks}

Diagram konteks adalah diagram yang menggambarkan hubungan antar Entitas Eksternal dengan sistem yang akan dibangun. Dimana data yang dimasukkan oleh bagian komponen eksternal akan diproses di dalam sistem dan akan menghasilkan laporan yang diinginkan oleh komponen eksternal tersebut sesuai dengan data yang dimasukkan

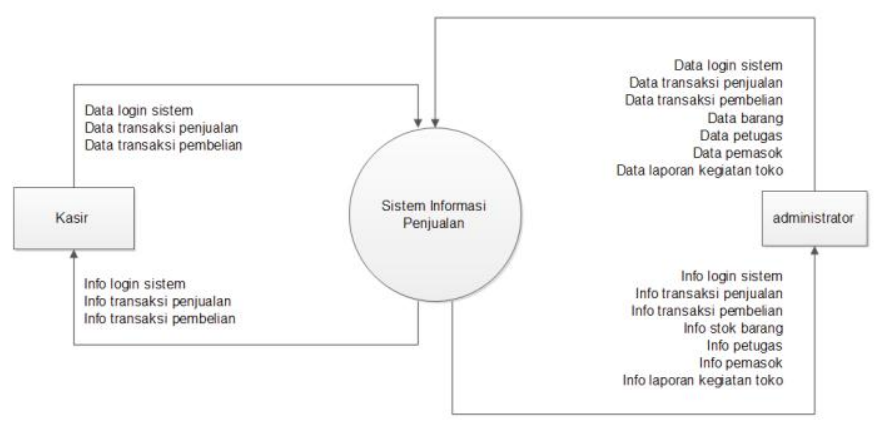

Gambar 1. Diagram konteks

Pada diagram konteks sistem informasi penjualan di Gambar 1 menunjukkan bahwa semua aliran data yang ada menuju pada satu proses, yaitu Sistem Informasi Penjualan. Terdapat dua entitas yang terlibat di sistem ini yaitu entitas Administrator dan entitas Kasir. Masing-masing entitas memiliki data masukan dan data keluaran pada sistem

a. Admin

Admin dapat melakukan seluruh proses yang terdapat pada sistem informasi penjualan ini.

b. Kasir

Kasir hanya dapat melakukan proses pada data login sistem, transaksi pembelian dan transaksi penjualan yang terjadi pada sistem informasi penjualan ini .

\section{Data Flow Diagram}

Data Flow Diagram (DFD) dibuat untuk menggambarkan arus data yang terstruktur dan jelas dari mulai pemasukan data sampai dengan keluarnya data. Arus data pada DFD ini berupa masukan untuk sistem oleh entitas eksternal atau keluaran dari sistem. DFD level 1 dapat dilihat dari Gambar 2. Pada DFD ini diberikan gambaran yang lebih 
spesifik tentang sistem. DFD level 1 ini merupakan pemecahan dari diagram konteks yang telah dijelaskan sebelumnya.

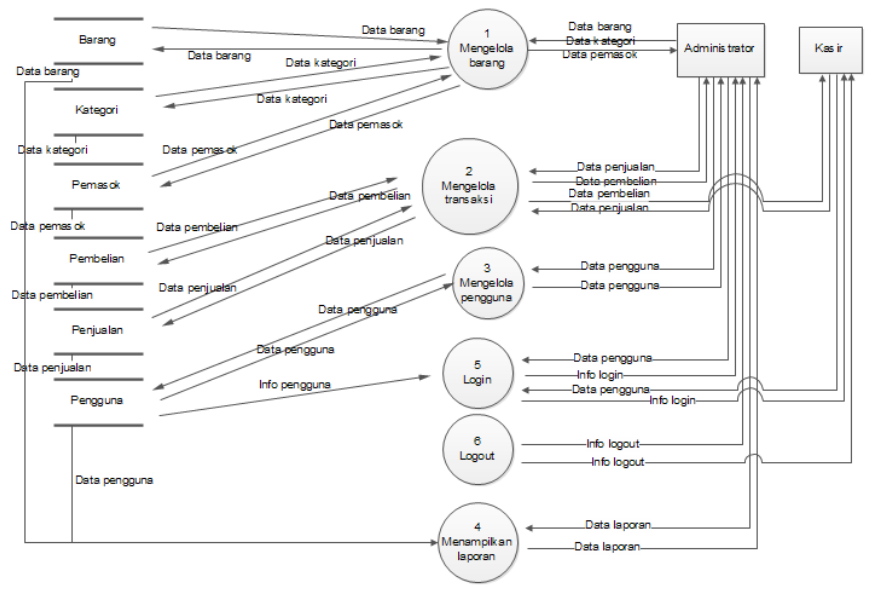

Gambar 2. DFD level 1

\section{Perancangan Basis Data}

Berikut dapat kita lihat E-R Diagram Sistem Informasi Penjualan dan Pembelian pada Toko PC Tablet.

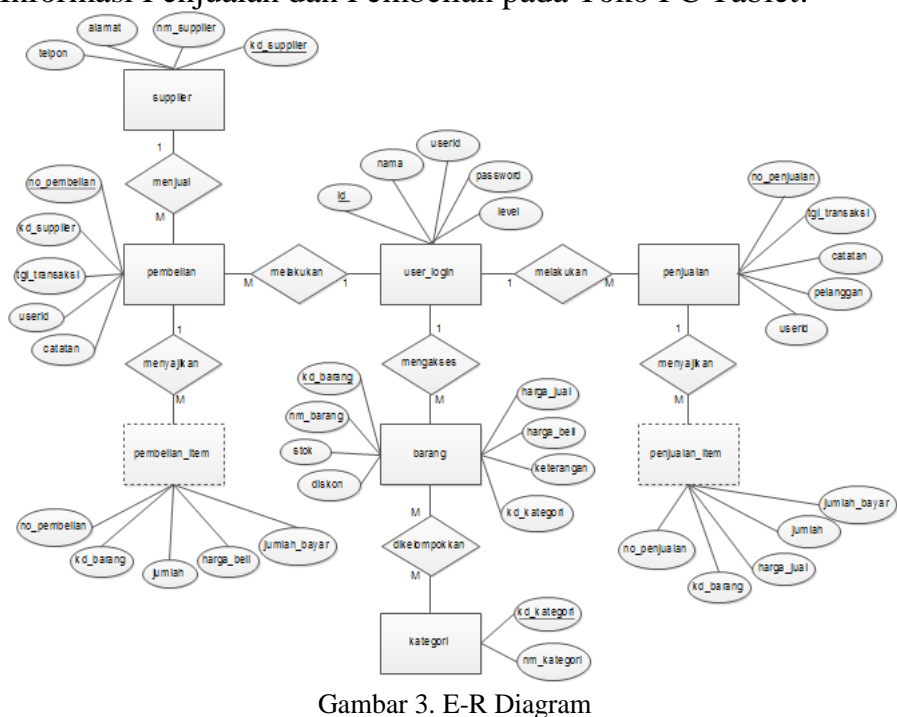

Gambar 3 dapat terlihat bahwa sistem informasi penjualan ini memiliki delapan entitas, antara lain : user_login, barang, kategori, supplier, pembelian, pembelian_item, penjualan, dan penjualan_item. Entitas user_login memiliki relasi dengan entitas barang, pembelian, dan penjualan. Relasi dengan entitas barang, pembelian, dan penjualan memiliki nilai kardinalitas one to many. Entitas barang memiliki relasi dengan entitas kategori dimana pada relasi tersebut memberikan nilai kardinalitas many to many. Entitas supplier memiliki relasi dengan entitas pembelian, pada relasi kedua entitas ini memberikan nilai kardinalitas one to many. Entitas pembelian memiliki relasi dengan entitas lemah pembelian_item, dimana pada relasi ini memiliki nilai kardinalitas one to many. Entitas penjualan memiliki relasi dengan entitas penjualan_item, dimana pada relasi ini memberikan nilai kardinalitas one to many.
IV.

\section{IMPLEMENTASI DAN PENGUJIAN SISTEM}

\section{A. Implementasi} dibuat.

Berikut adalah tampilan dari implementasi program yang

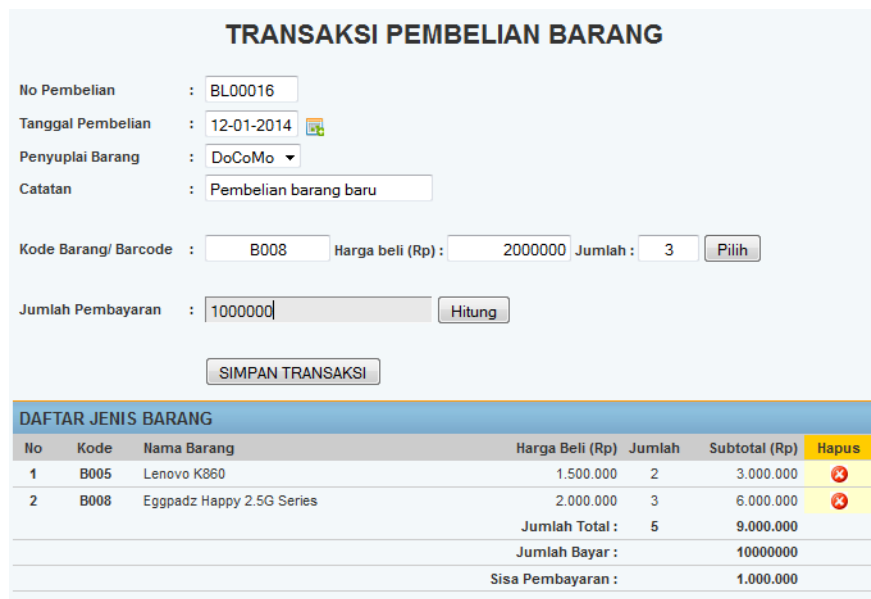

Gambar 4. Tampilan halaman transaksi pembelian barang

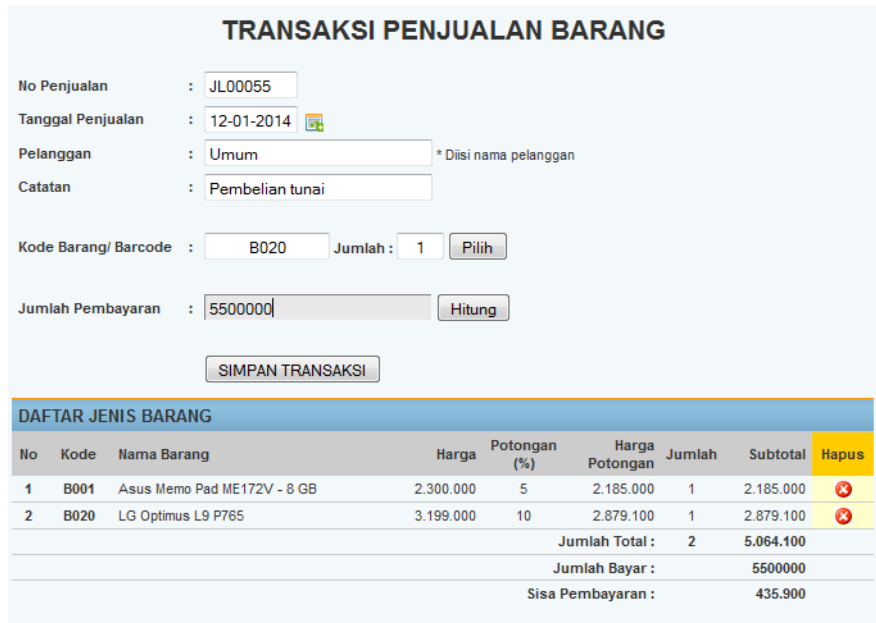

Gambar 5. Tampilan halaman transaksi penjualan barang

\section{B. Pengujian Sistem}

Pengujian sistem yang dilakukan pada sistem informasi terdiri dari dua pengujian, yaitu pengujian pada pengguna dengan level admin dan pengujian pada pengguna dengan level kasir.

Pengujian dengan level admin dilakukan pada setiap menu atau fasilitas yang dimiliki oleh level admin tersebut. Menu yang diujikan adalah login, pengolahan data pengguna, pengolahan data pemasok, pengolahan data barang, pengolahan data kategori, pengolahan data pembelian, pengolahan data penjualan, pengolahan laporan data barang, pengolahan laporan data pemasok, pengolahan laporan data pengguna, pengolahan laporan data kategori, pengolahan laporan data pembelian, pengolahan laporan data penjualan.

Pada pengujian di bagian login, dilakukan dengan beberapa langkah, seperti pengujian login dengan nama pengguna atau kata sandi yang salah, pengujian login dengan 
memberikan masukan angka pada kolom nama pengguna, dan pengujian login dengan tidak memasukkan nama pengguna atau kata sandi pada kolomnya.

Pada pengujian di bagian pengolahan data barang, dilakukan pengujian terhadap tiga fitur utama pada pengolahan data barang, yaitu tambah barang, ubah data barang, dan hapus data barang. Pengujian yang dilakukan pada pengolahan data barang juga dilakukan pada pengolahan data pemasok, kategori, dan pengguna.

Pada pengujian di bagian pengolahan data penjualan, dilakukan dengan beberapa langkah seperti memberikan masukan yang salah, menyimpan data ketika tidak dilakukan transaksi, dan mengubah data ketika data telah disimpan. Pengujian yang dilakukan pada bagian pengolahan data pembelian sama seperti pengujian yang dilakukan pada pengolahan data penjualan.

Pengujian pada level admin juga menguji pengolahan data laporan seluruh kegiatan pengguna. Pada pengujian di bagian pengolahan data laporan dilakukan dengan langkah seperti menampilkan laporan dengan periode yang terbalik dimana periode akhir dimasukkan pada kolom periode awal dan menampilkan laporan dengan masukan jenis kategori yang tidak terdapat di dalam penyimpanan data.

Pengujian dengan level kasir dilakukan juga pada setiap menu atau fasilitas yang dimiliki oleh level kasir tersebut. Menu yang diujikan adalah login, pengolahan data penjualan, dan pengolahan data pembelian.

\section{KESIMPULAN DAN SARAN}

\section{A. Kesimpulan}

Dari hasil pengujian dan analisis aplikasi sistem informasi penjualan dan pembelian pada Toko PC Tablet maka dapat disimpulkan hal-hal sebagai berikut.

1. Sistem informasi penjualan dan pembelian pada Toko PC Tablet menggunakan 10 tabel basis data dengan dua tabel berbentuk temporary (sementara).

2. Sistem informasi penjualan dan pembelian pada Toko PC Tablet memiliki dua level pengguna, yaitu administrator dengan hak akses penuh dan kasir dengan hak akses sebagian yaitu hak yang berhubungan dengan kegiatan transaksi toko.

3. Sistem informasi penjualan dan pembelian pada Toko PC Tablet menggunakan metode pengujian Black Box karena pengujian yang dilakukan berfokus pada kebutuhan fungsional yang dimiliki oleh sistem informasi penjualan ini.

4. Berdasarkan hasil metode pengujian Black Box setiap menu pada sistem informasi penjualan ini telah berjalan sesuai dengan sasaran yang dituju.

\section{B. Saran}

Sistem informasi penjualan dan pembelian pada Toko PC Tablet ini masih dapat dikembangkan lebih lanjut dengan perkembangan spesifikasi kebutuhan pengguna sistem yang harus dipenuhi dalam mencapai tahap yang lebih tinggi dan kinerja sistem yang lebih baik. Berikut adalah beberapa saran untuk pengembangan lebih lanjut :
1. Diharapkan untuk pengembangan selanjutnya sistem informasi dapat memberikan fungsi menu yang lebih lengkap dan juga dapat menampilkan data lebih spesifik dan jelas.

2. Diharapkan untuk pengembangan selanjutnya tampilan antarmuka dibuat menjadi lebih menarik dan efisien sehingga lebih memudahkan pengguna dalam pengoperasian sistem.

\section{DAFTAR PUSTAKA}

[1] Arbie, E. 2000. Pengantar Sistem Informasi Manajemen. Jakarta : Bina Alumni Indonesia.

[2] A.S, Rosa dan M. Shalahuddin. 2013. Modul Pembelajaran Rekayasa Perangkat Lunak. Jakarta : Modula.

[3] Connolly, Thomas, Carolyn Begg. 2002. Database Systems : A Practical Approach to Design, Implementation, and Management. England: Pearson Education,Ltd.

[4] Gilmore, W.Jason. 2008. Beginning PHP and MySQLfrom Novice to Professional. Apress.

[5] Inmon, William H. 2005. Building the Data Warehouse. Fourth Edition. Indianapolis : Wiley Publishing, Inc.

[6] Jogiyanto, HM. 2003. Sistem Teknologi Informasi. Yogyakarta : ANDI.

[7] Jogiyanto, HM. 2005. Analisis dan Desain Sistem Informasi. Yogyakarta: Andi Offset.

[8] Kadir, Abdul dan Triwahyuni, Terra CH. 2003. Pengenalan Sistem Informasi. Yogyakarta : Andi Yogyakarta.

[9] Kadir, Abdul. 2008. Tuntunan Praktis Belajar Database Menggunakan MySQL. Yogyakarta : Andi Offset.

[10] Krismiaji. 2005. Sistem Informasi Akutansi. Yogyakarta : Akademi Manajemen Perusahaan YPKN.

[11] Kristanto, Andri. 2008. Perancangan Sistem Informasi dan Aplikasinya. Yogyakarta: Gaya Media.

[12] Mcloed, Raymond, Jr.. 2001. Sistem Informasi Manajemen. Jakarta : Terjemahan Hendra Teguh Prenhallindo.

[13] Mauluddin, Syahrul. 2013. Pengembangan Sistem Informasi Apotek (Studi Kasus : Apotek Leuwi Sehat Majalengka). Jurnal Teknologi dan Informasi Bandung : Universitas Komputer Indonesia.

[14] Nana, Ramadijanti. 2008. Aplikasi Web Dasar Pemrograman PHP. Surabaya : Politeknik Elektronika Negeri.

[15] Nugroho, Bunafit. 2008. Latihan Membuat Aplikasi Web PHP dan MySQL dengan Dreamweaver. Yogyakarta: Gaya Media.

[16] O'Brein, James A.. 2005. Pengantar Sistem Informasi. Jakarta : Salemba 4.

[17] Pressman , Roger S. , Ph.D.. diterjemahkan oleh LN Hananingrum, 2002. Software Engineering : A Practioner's approach. New York : Mcgraw-Hill Book Co.

[18] Raharjo, B. 2011. Membuat Database menggunakan MySQL. Bandung : Informatika Bandung.

[19] Richard, Lungan. 2006. Aplikasi Statistika dan Hitung Peluang. Yogyakarta Yogyakarta : Graha Ilmu.

[20] Shelly, Woods . Introductory Concepts and Techniques. Gex publising service. 2001.

[21] Shudaryana, Putu, Cahyo Hidayanto, Bekti, dan Artowodini Muqtaditoh, Feby. 2012. Rancang Bangun Sistem Penilaian Index Kepuasan Pegawai Terhadap Lingkungan Kerja Melalui 
Dashboard Terintegrasi Dengan Menggunakan Metode Prototipe, Studi Kasus PT. PLN (PERSERO) Area Bali Selatan. Jurnal Teknik ITS Vol. 1. Surabaya : Balai Pustaka Fakultas Teknologi Informasi.

[22] Sutabri, Tata. 2005. Sistem Informasi Manajemen. Yogyakarta : Andi.

[23] Tantra, Rudy. 2012. Manajemen Proyek Sistem Informasi. Yogyakarta: Penerbit Andi.

[24] Westriningsih. 2012. Belajar JavaScript menggunakan JQuery. Yogyakarta : ANDI.

[25] Yunita, Ratih, Jemakmun, dan Tujni, Baibul. Agustus, 2012. Rancang Bangun Sistem Informasi Simpan Pinjam Pada Koperasi Ganesa Indah Balai Konservasi Sumber Daya Alam (KSDA) Sum-Sel Dengan Menggunakan Metode Prototyping. Jurnal Universitas Bina Dharma. Palembang.

\section{BIOGRAFI PENULIS}

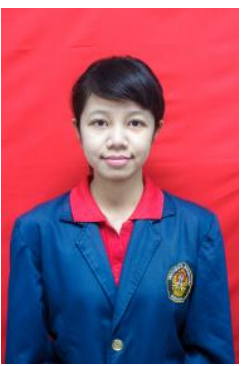

Nur Setyo Permatasari Putri W (L2N009033) lahir di Semarang pada tanggal 26 Agustus 1991. Bersekolah di SD Negeri Ngaliyan 08, SMP Negeri 16 Ngaliyan, SMA Negeri 06 Semarang dan kin menempuh pendidikan Strata satu di Program studi Sistem Komputer Fakultas Teknik Universitas Diponegoro. 
